\title{
Manajemen dental dalam memdokumentasikan kekerasan terhadap anak Dental management in documenting child's abuse
}

\author{
Mega M. Puteri \\ Departemen Ilmu Kedokteran Gigi Anak \\ Universitas Airlangga \\ Surabaya, Indonesia
}

\section{ABSTRACT}

Child abuse has increased dramatically over these present years. Child abuse occurs because of several reasons, such as poverty, low education background, and loss parents because of natural disasters. An estimate incidence of child abuse according to Komisi Nasional (Komnas) Anak in 2009 there are 1,998 cases, which is considerably high. It showed that society become more consciousness about child abuse. However, there is still small evidence of child abuse, due to lack of awareness, knowledge and skills on documenting child abuse. Moreover, most of the injuries of child abuse occurs at orofacial, so it is needed the awareness of dentist to understand the procedure in documenting child abuse. The purpose of this study is to improve knowledge and skill of the dentist in documenting child abuse.

Key words: dental management, documentation, child abuse, dentist

\section{ABSTRAK}

Dalam beberapa tahun ini terjadi peningkatan kekerasan terhadap anak. Kekerasan pada anak dapat terjadi oleh karena beberapa alasan, seperti kemiskinan, latar belakang pendidikan yang rendah, dan kehilangan orang tua akibat dari bencana alam. Menurut Komisi Nasional (Komnas) Anak pada tahun 2009 terjadi sekitar 1.988 kasus kejadian kekerasan pada anak, angka kejadian ini relatif cukup tinggi. Hal ini memberikan gambaran bahwa masyarakat mulai peduli kekerasan yang terjadi pada anak. Di sisi lain pembuktian akan terjadinya kekerasan pada anak masih termasuk sulit dilakukan, karena kurangnya pengetahuan dan keterampilan dalam mendokumentasikan terjadinya kekerasan pada anak. Karena kekerasan yang terjadi pada anak lebih banyak melibatkan daerah orofasial, maka diperlukan ketelitian dan keawasan dari dokter gigi untuk mengetahui prosedur dalam mendokumentasikan kekerasan pada anak. Tujuan penulisan dari makalah ini adalah untuk meningkatkan pengetahuan dan kemampuan dokter gigi dalam melakukan dokumentasi kekerasan yang terjadi pada anak.

Kata kunci: manajemen dental, dokumentasi, kekerasan pada anak, dokter gigi

Koresponden: Mega M. Putri, Departemen Ilmu Kedokteran Gigi Anak, Universitas Airlangga, Jl. Mayjen Prof Dr Moestopo no 47 Surabaya 60132, Indonesia.E-mail:mega_mp01@yahoo.com 